\title{
Individual Differences From His Learning Style And The Implications In Learning At Universities
}

\author{
Alchonity Harika Fitri ${ }^{1)}$, Jamaris Jamna ${ }^{2 *}$, Sofelma ${ }^{3)}$ \\ ${ }^{1)}$ Program Studi Doktor Ilmu Pendidikan Pascasarjana Universitas Negeri Padang \\ ${ }^{2,3)}$ Universitas Negeri Padang \\ *Coresponding Author \\ Email : Alchonity.hfa@gmail.com
}

\begin{abstract}
The study of individual differences in education explains differences related to differences in thinking, feeling and acting among students in a class. Educational levels from elementary school to college level have differences in learning styles. Effective learning is able to accommodate student needs. This is in accordance with the opinion of Sugihartono (2007) which says that one of the characteristics of effective learning is if learning can respond to student needs. Special needs relate to the uniqueness or differences between students. This individual difference in the learning process is the task of educators in understanding students, because they face students with various individual differences. This difference is normal and unavoidable. As a good teacher, the teacher cannot eliminate these differences by assuming all students are equal. Therefore, efforts are needed to address the differences of each student. Based on the study of literature from previous studies, it was found that students need to be considered in the learning process so that students can easily understand the learning material presented by the lecturer in the classroom.
\end{abstract}

Keywords: Individual Differences, Learning Style, University.

\section{INTRODUCTION}

Individuals in Latin are called "Individuum" which means "undivided". In the social sciences, the understanding of the individual, concerning life and a plural soul, plays a role in the association of human life. The individual is a limited unit, namely as an individual human being, not as a whole person. The Big Indonesian Dictionary (KBBI) states that an individual means a person: a person (separate from others). It can also be called individual which means about or relating to humans personally, individually. This is reinforced by the opinion of Echols \& Shadaly (1975), individual is a noun from individual which means person, individual, and person. The individual is also something that cannot be divided (undivided), cannot be separated, its existence as a separate, single and distinctive creature. A person is different from others because of his special characteristics (Webster's: 743). Based on the explanation above, it can be concluded that the individual is a human being who has a distinctive or specific role in his personality.

Individuals called humans are one of the creatures created by God. God created living things with various kinds, variations, and different characteristics, this is one of the keywords which states that humans are one individual creature that distinguishes them from other creatures (animals \& plants). Individual differences examine and explain how different people think, feel, and act. According to Lindgren, the meaning of "difference" and "individual difference" concerns the variations that occur, both physical and psychological variations. Individual differences according to Chaplin are quantitative traits or differences in a trait, which can distinguish one individual from another.

The study of individual differences in education explains differences related to differences in thinking, feeling and acting among students in a class. Educational levels from 
elementary school to college level have differences in learning styles. Effective learning is able to accommodate student needs. This is in accordance with the opinion of Sugihartono (2007) which says that one of the characteristics of effective learning is if learning can respond to student needs. Special needs relate to the uniqueness or differences between students.

This individual difference in the learning process is the task of educators in understanding students, because they face students with various individual differences. This difference is normal and unavoidable. As a good teacher, the teacher cannot eliminate these differences by assuming all students are equal. Therefore, efforts are needed to address the differences of each student.

\section{RESEARCH METHODS}

This research method uses a qualitative approach. a research method based on the philosophy of positivism, used to examine the condition of natural objects (Sugiyono. 2015). This study used the descriptive qualitative method. This research was conducted by collecting library sources, information, journals, books to obtain information as data sources called literature study. The articles taken are English and Indonesian articles related to individual differences. The exclusion criteria for the publication of articles are taken that display the abstract only.

\section{RESULTS AND DISCUSSION}

\section{A. Learning Style}

Learning style is closely related to personality and temperament. Personality is generally known as the overall attitude, expression, feeling, characteristics and behavior of a person. These personality and temperament attitudes will manifest in a person's actions when faced with certain situations. Willing (1988) defines learning styles as learning habits that are favored by learners. Keefe (1979) views learning style as the way a person accepts, interacts, and views his environment.

Drummond (1998: 186) defines learning style as, "an individual's preferred mode and desired conditions of learning." That is, learning styles are considered as ways of learning or learning conditions favored by learners. Learning style or learning style is a characteristic of cognitive, affective and psychomotor behavior, as an indicator that acts relatively stable for learners to feel interconnected and react to the learning environment (NASSP in Ardhana and Willis, 1989: 4).

Students are individuals who have high intellectuals, and their respective intelligences are more dominant, such as; speed in learning, learning performance and learning styles that tend to be different. The learning styles used by students Include;Visual (Learning Style by Seeing).

For students with a visual learning style, which plays an important role is the eye / vision (visual), in this case the teaching method used by the teacher should be more / focused on demonstrations / media, invite them to objects related to the lesson, or by showing the props directly to students or describing them on the blackboard. The characteristics of Visual learning styles nclude;

Speak a bit fast;

- $\quad$ Emphasize appearance in dress/presentation

- Not easily distracted by noise 
- $\quad$ Remembering what is seen, rather than what is heard

- $\quad$ Prefers to read rather than be read

- $\quad$ Fast and diligent reader

- $\quad$ Often knows what to say, but is not good at choosing words

- $\quad$ Prefers to do demonstrations over speeches

- $\quad$ Prefer music over art

- Has trouble remembering verbal instructions unless they are written down, and often asks someone to repeat them

\section{B. Auditory (Belajar dengan Mendengar)}

Auditory type students rely on their learning success through their ears (hearing devices), for that, teachers should pay attention to their students to their hearing devices. Children who have an auditory learning style can learn faster by using verbal discussion and listening to what the teacher has to say. Auditory children can digest the meaning conveyed through tone of voice, pitch (high and low), speed of speech and other auditory matters. Written information sometimes has minimal meaning for the auditory child to listen to it. Such children can usually memorize faster by reading text aloud and listening to tapes. Auditory learning style characteristics:

- $\quad$ At work like to talk to yourself

- $\quad$ Neat appearance

- $\quad$ Easily distracted by noise

- Learn by listening and remembering what was discussed rather than what was seen

- $\quad$ Enjoys reading aloud and listening

- Move their lips and pronounce the words in the book while reading

- Usually he is a fluent speaker

- $\quad$ Better to spell out loud than write it down

- $\quad$ Prefers oral jokes over reading comics

- Having problems with jobs involving Visual

- $\quad$ Speak in a patterned rhythm

- $\quad$ Can repeat and imitate tone, rhythm and tone of voice

\section{Kinesthetic (learning by moving, working and touching)}

Children who have a kinesthetic learning style learn through moving, touching, and doing. Children like this find it difficult to sit still for hours because their desire for activity and exploration is very strong. Students with this learning style learn through movement and touch. The characteristics of the kinesthetic learning style:

- $\quad$ Speak slowly and neat appearance

- $\quad$ Not too easily distracted by noisy situations

- $\quad$ Learning through manipulation and practice

- $\quad$ Memorizing by walking and seeing

- Use your finger as a guide when reading

- $\quad$ Finds it difficult to write but is great at story telling

- $\quad$ Loves books and they reflect the action with gestures while reading

- Loves busy games

- Can't remember geography unless they've been there Touching people to get their attention Using action words 
An explanation of the various learning styles above, can be described in the form of a Mind Map below;

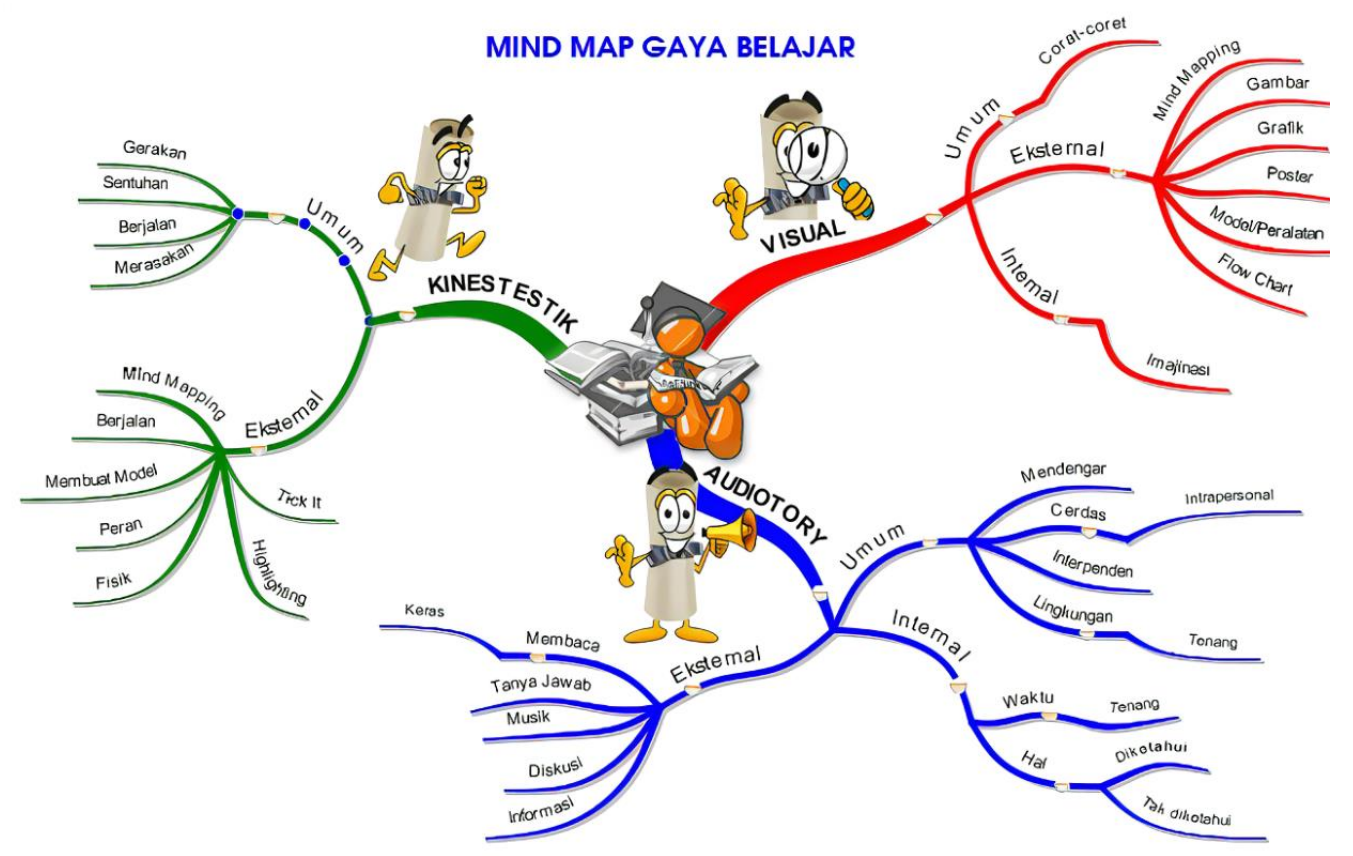

Figure 1. Maid Map Learning Style.

Based on previous research, explaining that the problems that occur in the fie ld are the result of educators not understanding and studying student learning styles in advance, which causes a lot of harm to students, this is proven by research conducted by Jeanet \& Neleke (2016) in their research entitled Identification of Styles. Student Learning that students have a tendency to one learning style, both visual learning style, auditory learning style, and kinesthetic learning style. Most of the students have a tendency of auditory learning style as many as 20 students. In addition, as many as 6 students have a tendency to visual learning styles, 1 student has a kinesthetic learning style tendency, and 12 students have a mixed learning style tendency between visual learning styles and auditory learning styles, students who succeed in learning in class because they have a different learning style. according to the teaching style applied by the lecturer in the classroom.

Furthermore, research conducted by Anthony Anggrawan (2019) with research results. Student learning outcomes who have auditory and visual learning styles who are taught using the online learning model have an average value of better learning outcomes than students who are taught by the face-to-face learning model. There is no difference in the average value of student learning outcomes who have a kinesthetic learning style between groups of students who are taught face-to-face learning and groups of students who are taught online learning.

Based on the results of the previous research above, it can be concluded that not only students in schools must be considered, at the tertiary level, students must also be considered in the learning process by lecturers. each student's differences, so as to achieve the goals of education.

\section{Implications and Strategies in Dealing with Individual Differences at the University.}

Learning style is closely related to personality and temperament. Personality is generally known as the overall attitude, expression, feeling, characteristics and behavior of a 
person. Even at the university level, every student also has a variety of ways and styles of learning, this can be seen in the learning process.

Students whose learning styles tend to be visual types or are more dominant in learning by capturing learning information with the sense of sight which they often do in the learning process can be seen in, a) the sitting position of students who are in the first order / row, this is done so that students can see clearly. clearly and more closely what is conveyed by the lecturer., b) the lecturer must display more diagrams, concept maps, flow-charts in explaining the materials/materials during the lecture. c) make an example of the subject matter in the form of a short story film, or a story and invite students to record important points related to the material., d). Illustrate and sketch/draw in learning in accordance with the teaching material.

Students whose learning style tends to the Auditory type, capture more learning through the sense of hearing. The things that must be done by the lecturer are; a) use audio such as music, radio, and so on. b) During the presentation, ask students to read aloud and aloud. c) Often make/throw simple questions to stimulate creativity in learning. d) Use recordings. e) Guide them in explaining and describing in words. f) Let them record what they understand about an eye subject. G) Study in groups.

urthermore, students with the kinesthetic type obtain/absorb more information through physical movement, using the body movement system. Things that can be done in maximizing their learning potential include: a) Learning through field practice (field trips). B) Doing performances such as drama, theater. C) learn by making extras/models/examples in real. D) Practical activities in the laboratory, and practice of motion in the field. E) More simulations and role playing and outdoor games can really stimulate learning.

\section{CONCLUSION}

Each individual has characteristics and traits or innate characteristics (heredity) and characteristics obtained from environmental influences. Innate characteristics are hereditary characteristics that are owned since birth. Each individual has various abilities that are general and also special abilities. This is an individual essence, that everyone is different.

Learning style is an individual's way of absorbing information/lessons, organizing, and managing information and applying it in life in solving problems. At the tertiary level, the focus of the learning process is the students. Students in learning use visual, auditory and kinesthetic learning styles in obtaining information. Based on the study of literature from previous studies, it was found that students need to be considered in the learning process so that students can easily understand the learning material presented by the lecturer in the classroom

\section{REFERENCES}

Eccho, Jonh M dan Shadhaly, Hassan. 1994. Kamus Inggris Indonesia, Jakarta: PT Gramedia Pustaka.

Sugihartono., Fathiyah, K. N., Harahap, F., Setiawati, F. A., \& Nurhayati, S. R. (2007). Psikologi Pendidikan. Yogyakarta: UNY Press.

Woolfock, Anita. 2009. Terjemahan. Prajitno, Muljantini. Educational Psychology. Jogjakarta : Pustaka Pelajar 
Email : editorijhess@gmail.com

Anthony Anggrawan, (2019). Analisis Deskriptif Hasil Belajar Pembelajaran Tatap Muka dan Pembelajaran Daring Menurut Gaya Belajar Mahasiswa. Jurnal MATRIK. Vol. 18. No. 2. Hal 339-346.

Slavin, E.Robert, 2008. Terjemahan. Samosir, Marianto. Psikologi Pendidikan, Teori dan Praktek. Jakarta: PT Indeks.

Smith, Mark. K, 2009. Teori Pembelajaran dan Pengajaran. Jogjakarta : Mirza Media Pustaka.

Sugiyono, 2015. Metode Penelitian Pendidikan (Pendekatan Kuantitatif, Kualitatif dan R\&D. Bandung: CV Alfabeta. 